\title{
Middle and high school teachers' implementation reflections of photonics and optics curriculum in a qualitative study
}

P. Gilchrist, T. Young, T. Bowles, K. Brady, L. Grable

P. O. Gilchrist, T. V. Young, T. A. Bowles, K. P. Brady, L. L. Grable, "Middle and high school teachers' implementation reflections of photonics and optics curriculum in a qualitative study," Proc. SPIE 10452, 14th Conference on Education and Training in Optics and Photonics: ETOP 2017, 104523K (16 August 2017); doi: 10.1117/12.2270958

SDIE Event: 14th Conference on Education and Training in Optics and Photonics, ETOP 2017, 2017, Hangzhou, China 


\title{
Middle and High School Teachers' Implementation Reflections of Photonics and Optics Curriculum in a Qualitative Study
}

\author{
${ }^{\mathrm{a}}$ Gilchrist, P. O., ${ }^{\mathrm{b}}$ Young, T. V., bowles, T. A., ${ }^{\mathrm{b}}$ Brady, K. P., \& ${ }^{\mathrm{a}}$ Grable, L. L. \\ ${ }^{a}$ The Science House, North Carolina State University, 909 Capability Drive, Raleigh NC USA 27695 \\ United States, ${ }^{\mathrm{b}}$ College of Education, North Carolina State University, Raleigh NC United States \\ 27695
}

\begin{abstract}
The purpose of this paper is to describe middle and high school science teachers' self-reported experiences learning and adopting novel optics and photonics content. The hybrid teacher professional development program design, theoretical framework, methodology, findings, and implications related to teachers' adoption decisions of optics and photonics content will be reported in the paper.
\end{abstract}

Keywords: optics and photonics content; teacher professional development; e-learning; science education; adoption of innovations, STEM, teacher reflection

\section{INTRODUCTION}

In 2005, the founding Director of The Science House and a Director of Imhotep Academy (a STEM program) within the College of Sciences at North Carolina State University established the first photonics student outreach program, Photonics Leaders. Photonics is a branch of physics related to light, laser technology, electrical engineering, materials science, and optics. The goal of the Photonics Leaders program was to prepare underrepresented minority high school students for higher education, in general, and STEM majors, in particular by immersing students in physics content, internships, and college learning experiences. Grounded by the internal and external evaluation reports of Photonics Leaders and empirical research, the Photonics Leaders II (PL2) program was established to improve science teachers' knowledge of physics and technology.

The primary purpose of PL2 was "to cultivate a world class and broadly inclusive science and engineering workforce; and to expand the scientific literacy of all citizens" (This hybrid year-round science and technology-based program sought to expand underrepresented minority sophomore and junior students' awareness of STEM careers, requisite STEM courses, and information technology (IT) competencies by explicitly incorporating teachers and parents. PL2's program's priorities were recruitment and preparation of underrepresented minority high school students for STEM careers, transformation of teachers and parents' perceptions of how to prepare students for STEM fields, and the dissemination of curriculum products and findings to broader audiences. To facilitate student success and teacher change (professional development, the program model incorporated STEM activities and partnerships with scientists and engineers from academia, government, industry, education, and community settings into its program format to enhance teachers' knowledge of optics and photonics). The current paper will focus on the teacher professional development component of the Photonics Leaders II project, PBLTPD and middle and high school teachers' reflections of their learning and content adoption decisions related to adoptions of innovations construct of Roger's Theory of Innovation

\section{PHOTONICS BLENDED LEARNING TEACHER PROFESSIONAL DEVELOPMENT (PBLTPD)}

PBLTPD is an intensive hybrid (face-to-face and online) program for middle and high school teachers. PBLTPD's objectives are:

14th Conference on Education and Training in Optics and Photonics: ETOP 2017, edited by Xu Liu,

Xi-Cheng Zhang, Proc. of SPIE Vol. 10452, 104523K · ( 2017 ICO, IEEE, OSA, SPIE

CCC code: $0277-786 X / 17 / \$ 18 \cdot$ doi: $10.1117 / 12.2270958$ 
1. To introduce and model instructional strategies for effectively teaching photonics content, promoting awareness of STEM careers, and preparing students for the global workforce;

2. To enhance teachers' skills, knowledge, and behaviors toward teaching physics to all students, especially under-represented minority students; and

3. To document changes in teachers' classroom practices that impact students' STEM outcomes.

The program format consisted of: (a) face-to-face learning intervention comprised of an inquiry, internship, and technology component, (b) an eight-month implementation component which included teachers developing an implementation plan, implementing lessons, and reflecting on the learning experience, and (c) an online follow-up component for participants to reflect upon their learning experiences and learn new photonics problem-based learning curriculum. Each program component was purposefully designed to introduce participants to physics content, inquirybased instruction, web-based technology tools, and STEM careers. Participants were required to complete all parts of the workshop to receive a $\$ 500$ stipend and to provide feedback on the impact of program interventions. In three years, the program provided professional development to 57 teachers from 30 counties and five states, North Carolina, Maryland, South Carolina, New Hampshire, and Virginia $1^{1}$.

\section{ROGER'S ADOPTION OF INNOVATIONS THEORY}

The process by which science teachers choose to integrate a new idea, program or approach into their classroom can be examined through Rogers's diffusion of innovation theory ${ }^{2}$. This framework provides an approach for investigating how participants make sense of the professional development experience and the consequences of that experience for future classroom experiences ${ }^{3}$. Rogers described an innovation as a new idea, practice, or object that is perceived as new by an individual or other unit of adoption (p. 12). In this study, the innovations are physics (optics and photonics) content, inquiry-based/constructivist instructional approaches, web-based learning tools, and a hybrid-learning environment. According to Rogers, uncertainty obstructs adoption of innovations. So, uncertainty must be reduced to facilitate adoption. By participating in PBLTPD, where teachers interact with the innovations and learn about the advantages and disadvantages associated with the innovation, it was hypothesized that uncertainty could be reduced. Specifically, uncertainty could be reduced by teachers' engaging in interpersonal communications through different communication channels - in the case of PBLTPD, the workshop environment for teacher learning and discourse; tours of research laboratories, interaction with experts in the field. On-site implementation planning, integration at local school site and online sessions also should facilitate diffusion because new information, ideas and strategies are communicated over channels to members in different social systems.

The innovation decision process is comprised of five stages: knowledge, persuasion, decision, implementation, and confirmation. Generally, these stages occur in a time-ordered process and are influenced by characteristics of the innovation. Using the first three stages of this model as a framework allows for the assessment of how teachers first learned about PBLTPD, what persuaded them to participate in the workshop, and what factors led them to decide to implement or not implement the research-based strategies in their classroom, or other settings.

In the persuasion stage, the potential adopters of innovations consider the relative advantages, compatibility, observability, trialability, and complexity of an innovation. During the persuasion stage, the adopter becomes "more physiologically involved with the innovation, develops a favorable or unfavorable attitude, and anticipates present and future use of innovation before overtly displaying a behavior to try it or not" iii. The decision to adopt is influenced by the perspective adopter's assessment of the innovation with evaluation information compiled from personal experiences and peer opinions. Information is used to reduce uncertainties about the innovation. By outlining the relative advantages (the economic and social advantages of the innovation); compatibility of the innovation with existing beliefs, past experiences and potential needs of adopters; complexity (the potential adopters' difficulty in using or understanding the innovation); trialability (opportunities for potential adopters to experiment with the innovation); and observability (visible results or use in social system), the adopter decides to adopt or reject an innovation. The fourth stage, implementation, provides a lens for examining teachers' experiences using the innovations presented in PBLTPD. The fifth stage, confirmation, addresses why teachers decide to continue or not continue to teach or use PBLTPD content, inquiry-based strategies, and web-based technologies in their classroom. Generally, using Rogers's diffusion of innovation decision process will allow one to gain insight about how the attributes of the different innovations that comprise PBLTPD influenced their adoption after completing the workshop 


\section{RELEVANT LITERATURE}

PBLTPD, a small-scale professional development design for science teachers integrated Darling-Hammond's elements for effective teacher professional development ${ }^{4}$. Table 4.1 outlines PBLTPD program strategies were aligned with Darling-Hammond's components to establish an active and reflective learning environment for teachers to interact as learners and professionals in their professional development program and their classroom to lead to new teaching behaviors.

Table 4.1

Elements of Effective Teacher Professional Development and PBLTPD Design Strategy

\section{Number}

1

Engage teachers in practical tasks and provide opportunities to observe, assess, and reflect on the new practices

2

Be participant driven and grounded in inquiry, reflection, and experimentation

3 Be collaborative and involve the sharing of knowledge

$4 \quad$ Directly connect to the work of teachers and their students.

$5 \quad$ Be sustained, on-going and intensive

7

Provide support through modeling, coaching, and the collective solving of problems

$8 \quad$ Be connected to other aspects of school change (DarlingHammond, 2006)

\section{PBLTPD Design Strategy}

Teacher engagement in inquiry hands-on activities in learning labs with peers, with research scientists, completing daily reflections, implementation plans, and assessments. Laboratory tours and practicum in Component 1, 2, and 3.

Hands-on activities/orientations in face-to-face and online component (i.e., build spectroscope, polarizer, create holograms, parallel and series circuit activities, fiber optics hands-on activities), problem-based learning problem analysis activity and presentation in Elluminate, e-group discussions and reflections on instructional strategy in Component 1, 2, 3, 4 and 5.

Group and individual work, creation of implementation plans and discourses with middle school and high school teachers. Presentation of implementation activities, discourse with staff, researchers, and fellow teachers in Component 1, 2, 3, 4, and 5.

Implementation of plans into classroom and school, curriculum piloting and year-round job with student program in Components 4 and 5 .

Extended community of practice of discourse through Moodle, Elluminate, access to Elluminate coordinator and project staff, and continual learning of constructivists' approaches in live follow-up session over six months in Components 4 and 5.

Project model and support collective solving of problems (i.e., how to arrange tours with scientists, login into Moodle, Elluminate, learning environment interfaces) in Components 4 and 5).

Support national STEM goals, encourage presentation of materials to administrative staff and colleagues, participation in student program component, time to develop leadership skills as an educator in Phases 1, 2, 4 and $5\left(^{5}\right)$.

Note: Adapted from Darling-Hammond ${ }^{5}$ 


\subsection{Blended Learning Research}

Blended learning has enhanced, challenged, and extended teaching and learning experiences of adult learners for more than 50 years ${ }^{6,7,8}$. First, it stretched industry instructor-led classes by removing the boundaries of time and location. Through training courses, it integrated options for meeting the diverse career advancement needs of professionals ${ }^{7}$. It also challenged traditional methods of teaching and learning by requiring that adult learners and educators use technology hardware, software, and networks in ways that enhanced accessibility, affordability, and educational needs ${ }^{7,9}$ . Lastly, it has enhanced the range of teaching and learning approaches with adults through the incorporation of diverse learning modalities, techniques, resources, and tools used for the investigation of educational, societal, medical, and economic problems ${ }^{10,11}$

Researchers have examined different constructs of blended learning ${ }^{12,19}$. Driscoll's (2002) research, for example, examined different learning strategies for blended learning ${ }^{13}$. Other researchers have investigated the education outcomes of blended learning ${ }^{14,15}$. Christensen (1997) examined the transformative nature of technology on adults within an organization to determine application of technology. Dzuiban, Hartman \& Moskai investigated blended learning's impact in higher education, and Graham sought to discover how to best optimize blended-learning environments with the right" learning technologies and the "right" learning for the "right" person at the "right" time ${ }^{\mathrm{xi}, \mathrm{xv}}$.

Decades of research on blended learning have influenced adult learners. During the 1960s, blended learning began within the corporate setting, rapidly infused higher education in the 1980s, and is now gaining considerable ground in the K-12 arena ${ }^{8,15,1016}$. Research within these sectors has shown blended learning can be effective with adult learners given certain circumstances, notably the identification of blended learning's advantages, interaction with experts who use the approach, training that presents how to use the environment and strategies, and time to use the environment and plan lessons that incorporate pedagogical, social, managerial, and technological strategies ${ }^{17}$.

\subsection{Content Knowledge}

For more than 30 years, a plethora of professional development programs initiatives have focused on increasing teachers' content knowledge and skills ${ }^{18,19}$. The greatest need for in-service teacher training is content-focused professional development ${ }^{20}$, because for teachers to be effective they must have confidence in teaching science content before attempting to integrate different pedagogical strategies ${ }^{21}$. Furthermore, many high school and middle school teachers lack an understanding of light, force, and motion concepts, yet there have been only a limited number of workshops that focus on physical science and physics content for high school teachers ${ }^{22}$. Thus, an important goal of PBLTPD design model was to introduce middle school and high school teachers to the physics of light content, its ubiquitous applications, and its content connections.

Through a hybrid format, PBLTPD introduced teachers to the physics of light content that is often not provided in continuing education opportunities at local schools for teachers ${ }^{23,24}$. While PBLTPD model focused mainly on light and optics, it also incorporated laboratory tours and field experiences with experts in physics, engineering, and technology - an experience often viewed as one of the essential elements in preparing teachers for 21st century schools, yet one that is not commonly offered through teacher professional development ${ }^{24}$. Also, because PBLTPD is offered in a blended learning format, this study provides insight into how using the hybrid platform relates to development of teachers' content knowledge about the physics of light.

The literature on the professional development (PD) of teachers reveals several key features of effective PD for teachers ${ }^{25}$. Generally, the research suggests the teachers need to know more content, how to teach the content, and what tools to teach content; it also shows the traditional methods for delivering professional development has fallen short in meeting these needs ${ }^{26,22,23}$. PBLTPD was intentionally designed to address these deficiencies and others described in the literature from three different disciplines: a) teacher education (teachers in general and science teachers in particular), b) information technology education, and c) adult education ${ }^{21,27}$. 


\subsection{Reflection}

PBLTPD implementation and follow-up components incorporated adult learning principles to support teachers' classroom implementation needs to foster the integration of new practices and teacher reflection. Darling-Hammond and McLaughlin (1995) assert that teacher reflection on their practice is necessary for teachers to integrate new knowledge and beliefs regarding content, pedagogy, and learners into their classroom ${ }^{28}$. Several frameworks have been used to understand teachers' learning, their implementation behaviors, and factors impacting classroom implementation ${ }^{29,30}$. Guskey suggest one way to measure change in teacher practices is for teachers to document the impact of implementation on student achievement. Sandholtz and colleagues applied a three-stage process to understand teachers' adoptions of technology into their classroom in the Apple Computers of Tomorrow program. They found that teachers generally move through a survival, mastery, and teacher change plateau when adopting technology ${ }^{32}$.

Reflection also contributes to implementation. Schon describes teacher reflection as a reflective practice that involves thoughtfully considering one's own experiences while applying knowledge in coached settings ${ }^{31}$. The process by which teachers reflect can occur through one or all three types of reflection: cognitive, critical, and narrative reflection. Cognitive reflection pertains to how a teacher processes information and makes decisions. Research on teachers' cognitive reflection has focused mostly on teachers' reflection of content knowledge, pedagogical methods and theory, curriculum, and learner characteristics ${ }^{23}$. According to Shulman, more research is needed on teachers' reflection on teaching contexts and educational purposes, ends and aims. Critical reflection focuses on the substance that drives teachers' thinking, experiences, goals, values and social implications. Research on critical reflection has shown that it provides a basis for clarifying how teachers think about dilemmas of teaching and its social outcomes in education ${ }^{\text {xxiii }}$. Narrative reflection refers to a teacher's interpretation of the events that occur in their particular contexts. Research on narrative reflection has provided insight on what motivates teachers' actions and the complexity of their everyday lives. Darling-Hammond and McLaughlin (1995) have documented the need for "teachers to reflect critically on their practice to fashion new knowledge and beliefs about content, pedagogy, and learners" (p. 592) ${ }^{30}$. To facilitate the adoption of research-based practices for instructional purposes, PBLTPD provided science teachers opportunities to reflect on their practices, pedagogical beliefs, knowledge, and experiences.

\section{RESEARCH QUESTIONS}

The research questions guiding this study are:

1. What are teachers' experiences in the Photonics Blended Learning Teacher Professional Development program?

2. How do teachers implement innovations from the Photonics Blended Learning Teacher Professional Development?

a. How do participants implement photonics concepts?

b. How do participants implement inquiry-based approaches?

c. How do participants implement web-based technologies?

3. What facilitates or impedes science teachers' implementation of Photonics Blended Learning Teacher Professional Development innovations?

\section{METHODS}

A qualitative, instrumental case study design was used to examine the experiences of 15 middle and high school science teachers in PBLTPD and their implementation of innovations presented in the program. The teachers taught at public, charter, and alternative schools representing school districts in nine North Carolina rural and urban counties that represent tier one, two, and three economically-distressed areas. According to Patton, the case study approach enables the researcher to investigate the why and how of decision making, not just where, what, and when ${ }^{32}$. Yin (2003) describes a case study as an "empirical inquiry that investigates a contemporary phenomenon within its real-life context, especially when the boundaries between the phenomenon and context are not clearly evident" (p. 13) ${ }^{33}$. For this study, the instrumental case study approach was selected to understand teachers' experience in PBLTPD program and their implementation of the components post-intervention.

A semi-structured interview protocol was used to interview teachers on the telephone to gain insight about how teachers' decisions to adopt or reject an innovation introduced in PBLTPD. Interviews, on average, lasted about 45 minutes. 
Program documents, implementation reflections, Elluminate session recordings, and program report data were examined as well. The data were coded using a constant comparative method to identify categories that correspond to the research questions ${ }^{34,35}$.

\section{FINDINGS}

This section presents findings related to the teachers' reflections of their learning experiences and implementation efforts. Middle and high school teachers' reflections focused on content knowledge, teaching strategies, curriculum resources and materials and relevance of optics and photonics laboratory tours.

\subsection{Content Knowledge}

The middle and high school teachers attended PBLTPD workshop because they were seeking a more content-focused professional development that would provide them the opportunity to learn new information. They described the workshop as well-organized, fun, intensive, and informative to them as science educators.

Teachers expressed that they learned optics and photonics content that they did not know prior to participating in PBLTPD. Lynn, a high school teacher who taught physical science and a "Future Decision in Science" course, shared what she learned from the professional development:

"Well, there are a couple of different areas. One thing I learned was about the nature of photonics, how it acts as a wave and a particle, and just, I guess, the content about photonics was one thing that was very useful to me, which I alluded to in my first question. I knew it was a wave particle - I knew that, but then the many ways that is being studied and the many uses it has. So that was the first thing I learned the content."

Molly, a high school teacher with fourteen years of experience, decided to participate in the workshop because it covered the science of light, which she could add to her teaching repertoire. She described how she learned about fiber optics. In contrast, Susan, a veteran sixth grade teacher, wanted to learn more about light which is part of the sixth grade [North Carolina] Essential Science Standards, but learned not only about light but also other concepts:

"There were just so many things that I have gotten out of that workshop and put into practice in my classroom. The list really is endless, not only from what you all taught, but just talking to other teachers that were there and things that they did in their classroom. I mean I could hit some high spots like angle of reflection, you know, and things associated with that. The LCD (liquid crystal display) circuits-I use those now with the kids. Nanotechnology was something that I really couldn't have talked to my kids about at all, and now I feel like I can at least explain it to them, especially the poster that you all had there. We talk about jobs and careers for kids that, you know, they're not going to think about that I didn't know about either. Wow. Understanding how the human body perceives light and colors and other structures, all of that."

All in all, the participants' data revealed that PBLTPD provided them opportunities to learn about the basics of light, its tendencies and applications that could be used in their classrooms.

\subsection{Curriculum Materials and Activities}

The teachers in the study represented rural and urban school districts and varying experience with teaching optics and photonics content. The teachers discovered new curriculum materials and activities to support their use of the content in their respective classes and schools. Lynn is a high school environmental science teacher from an urban county. She shared that the materials and activities would enhance her students' understanding, especially the "Mirror, Mirror on the Wall" angle of reflection activity. Several of the teachers shared that the curriculum activities and resources introduced in PBLTPD were new, interesting, relevant, and provided practical applications for the classroom. For example, George described how the materials and activities from PBLTPD complemented his new understanding of the concepts:

"A lot of PDs - professional developments - we have at the school are one day or one hour, and that's not enough. That's not enough to really get anything out of it, and the application part of it is even tougher because you don't have time to get deep into something you just learned and you're really excited about trying it. So the photonics program offered practical applications of a lot of the concepts and activities that we were able to get and to work with the students." 
Janet reported how the photonics materials and resources she acquired in the program two years ago now aligns with the new Essential Science Standards in North Carolina; she also stated that they were easy-to-implement and exciting. Janet shared:

"They [curriculum materials and activities] were new; they were exciting. Some of them, it didn't take a lot of materials. I was given a fiber optic box that has the fibers in it, and I was able to use those things that were given to me. I have a number of things that were given to me from different facilitators, so I was able to use those things in a demo. If I didn't have enough for students, I had enough to show to them and do a teacher demo, so I used those things that were given to me during that workshop. Our new essential standards now, a lot more of those things that we were doing in this workshop that I did two years ago are in the new official standards such as the bubbles interferences \& the Tyndall effect. So I was able to use the labs that I did two years ago on a unit now with objectives that have changed."

Additionally, Regina claimed that the use of curriculum materials and resources related to light perception, solar cells, lenses, image formation, and problem-based learning modules with sixth graders were much needed enhancements to her unit on light traditionally taught didactically:

"I have used different activities like a bag full of objects [used to explore] how light is perceived. Some of them are easy and some of them are really hard. And, I have also used solar panels [with] different kinds of connections. So those are specifically different things that I have used and I'm still using the hands-on activities that were geared toward how light is perceived; problem-based learning module; and the hardware we were using — the lenses to see how an image is perceived."

Lastly, Paul noted how the activities and materials he acquired from the program were such great activities that he used what he could not utilize in his classroom with an afterschool program because they were relevant and would facilitate students' independent exploration and understanding of science:

"I've used it in my after-school Science Club to work with the interested students there to demonstrate a lot of information or things about light, electricity, and ideas for electronics and to give kids some hints for science fair to give ides for science fair project."

\subsection{Teaching Method}

Jim, a teacher from a rural under-resourced high school, discussed how his PBLTPD experience contributed to expanding his awareness of different instructional strategies for teaching waves and optics, which he believes are rather complicated concepts to teach students. He shared:

"It had been so long since I had studied anything with physics with waves and stuff, and learning some pretty-not complicated, but not simple - ideas as far as trying to get waves across to kids and dealing with optics and how to apply different ways of teaching and reflection and things like that go hand-in-hand with the actual course curriculum."

Paul also learned new approaches to demonstrate light and other concepts to school students, saying, "Well I learned some ways to demonstrate some of the characteristics of light and things that you can do with light with my kids although it doesn't work as well in our new standard course of study." Regina shared how her experience in PBLTPD provided her the confidence to use more inquiry-based teaching methods with students in her class rather than traditional lecture style approaches for her light unit. She shared the following:

"I came to know different things that I could do with more hands-on learning, but earlier when I used to teach this curriculum, it was more like lecture and it was more like showing visuals, but I did not do many hands-on activities that could go with the curriculum, so attending this workshop helped me figure out."

\subsection{Optics and Photonics Applications, Research, and Careers}

The university and industry laboratory tours exposed the teachers to research, its future, real-world applications and STEM career information. 
As Ann explained,

"I think one of the most valuable things I learned is where the kids are headed." Ann also explained that the tours and interactions with physicists and engineers provided her a vision for the future of science and helped her better understand what students needed to know. Janet was especially appreciative of the opportunity to see real research because she had not had access to actual research laboratories in other professional development programs in her district."

Thomas also valued the lab tours. He shared:

"I really liked the labs course that we did and the different equipment that was available there at State for them to look at ... Like the laser imaging and vibrational spectroscopy lab tour was really interesting. I also had a lot of fun creating the liquid crystal display pixel. That was pretty cool. But, the lab tour component was one of the most interesting experiences I had at the workshop."

Janet made remarks about the advantage of participating in a teacher professional development where she learned about real research, toured the actual laboratories, and shared her assessment:

"Well, in comparison, my school district, when we go to our professional development, we don't have a university-well, we have a university, but our university doesn't have all the different-[equipment \& instrumentation]. They don't have the textile labs or the type of labs that NC State like the clean lab. They didn't have it on a broad scale. The schools there, in my local area, are very limited. So attending this workshop, I was very excited to actually go onto NC State campus and actually go into those different laboratories that are in the industry, and so in comparison, I didn't get that experience in my local schools' professional development."

\section{CONCLUSION}

Middle and high school teachers learned new content, activities, teacher strategies, career information, how to collaborate, how to facilitate collaboration in their classroom, and gained a broader awareness of web-based technology strategies by participating in the hybrid teacher professional development. Teachers experienced challenges learning in the hybrid platform. In the face-to-face learning environment, teachers experienced difficulty with the scope, volume, and depth of content, interacting in a cross-disciplined learning environment, and translating learned content for student learning.

Many middle and high school teachers used the optics and photonics content in their classrooms, professional learning communities, and in extracurricular programs, especially during and immediately after the program. The findings also revealed that teachers used inquiry-based strategies to differentiate their instruction in their classrooms, for further investigation through participating in additional professional development programs, and as an approach to support the development of their confidence with implementing the strategy. Generally, middle and high school teachers implemented content, materials and inquiry-based activities to use in their classroom for instructional purposes.

Based on Rogers's attributes of innovation theory, the most important facilitators were relative advantage, compatibility, and motivation. The prominent barriers for use of the content, inquiry-based strategies, and web-based technology from the theoretical perspective was complexity. Future research on optics and photonics teaching professional development programs with middle and high school teachers could investigate how to reduce complexity in the learning experience by extending the length of the professional development to address content, instructional, careers, and research innovation.

\section{References}

${ }^{1}$ Gilchrist, P. \& Bowles, T. (2011). National science foundation innovative technology experiences for students and teachers annual project outcome report: Photonics Leaders II. [Report No. 3] Arlington, VA.

${ }^{2}$ Rogers, E.M. (2003). Diffusion of innovations (5th ed.). New York: Free Press.

${ }^{3}$ Ferguson, 2007

${ }^{4}$ Darling-Hammond, L., Endowment, R. \& E. L. K. L. (2006). Powerful teacher education: Lessons from exemplary programs. The Jossey-Bass education series (1st ed.). San Francisco, CA: Jossey-Bass 
${ }^{5}$ Gilchrist, P. Hilliard-Clark, \& Bowles, T. (2010). Optics professional development in north carolina. Proceedings of the International Society of Optics and Photonics (SPIE) Conference, San Diego, CA, 7429, 7783, 7783041-7783049. doi: $10.1117 / 12.861057$

${ }^{6}$ Bersin, J. (2004). The blended learning book: Best practices, proven methodologies and lessons learned. England: John Wiley and Sons.

${ }^{7}$ Dede, C. (2010). Comparing frameworks for 21st century skills. In 21st century skills: Rethinking how students learn, 51-75, edited by J. Bellanca and R. Brandt. Bloomington: Solution Tree Press

${ }^{8}$ Hartman, J. C. Dziuban, \& Brophy-Ellison, J. (2007). Faculty 2.0 EDUCause Review 42, No. 5: 62-77. Retrieved from http://www.educause.edu/ Hew, K. F., \& Brush, T. (2006). Integrating technology into K-12 teaching and learning: Current knowledge gaps and recommendations for future research. Educational Technology Research and Development, 55, $223-252$. doi:10.1007/s11423-006-9022-5

${ }^{9}$ Picciano, A. G., \& Seaman, J. (2008). K-12 online learning: A follow-up of the survey of U.S. school districts administrators. The Sloan Consortium. Retrieved from http://www.sloan-c.org/publications/survey/pdf/k-12_online_learning_2008.pdf

${ }^{10}$ Dzuiban, C. D., Hartman, J. L., \& Moskal, P. (2004). Blended Learning |EDUCAUSE. Retrieved September 3, 2011, from http://www.educause.edu/ECAR/

${ }^{11}$ Nagel, D. (2011). Report: 6 Blended Learning Models Emerge -- THE Journal. Retrieved September 2, 2011, from http://thejournal.com/articles/2011/05/04/report-6-blended-learning-models-emerge.aspx

${ }^{12}$ Christensen, C.M. (1997). The innovator's dilemma: when new technologies cause great firms to fail. The Management of Innovation and Change Series. Boston, Massachusetts: Harvard Business School Press.

${ }^{13}$ Driscoll, M. (2002). "Blended learning: Let's get beyond the hype.” E-Learning, Vol. 3(3), p. 54

${ }^{14}$ Graham, C. (2005). Blended-learning systems: Definitions, current trends and future directions. In The blended learning handbook (pp. 1-21)

${ }^{15}$ Singh, H., \& Reed, C. (2001). A white paper: Achieving success with blended learning. doi:10.1.1.114.821

${ }^{16}$ Voogt, J. (2010). Teacher factors associated with innovative curriculum goals and pedagogical practices: Differences between extensive and nonextensive ICT using science teachers. Journal of Computer Assisted Learning, 26(6), 453-464. doi:10.1111/j.13652729.2010.00373.x

${ }^{17}$ Kaleta, R., Skibba, K., \& Joosten, T. (2007). Discovering, designing, and delivering hybrid courses. In A. G. Picciano \& C. D. Dziuban (Eds.), Blended learning: Research perspectives (pp. 111-143). Needham, MA: Sloan Consortium.

${ }^{18}$ Darling-Hammond, L., Wei, R. C., Andree, A., Richardson, N., \& Orphanos, S. (2009). Professional learning in the learning profession. Washington, DC: National Staff Development Council. Retrieved from

www.srnleads.org/resources/.../pdf/nsdc_profdev_short report.pdf

${ }^{19}$ Loucks-Horsley, S., Stiles, K. E., Mundry, S. E., Love, N. B., \& Hewson, P. W. (2009). Designing professional development for teachers of science and mathematics (3rd ed.). Corwin Press

${ }^{20}$ School and Staffing Survey, 2000, 2004, 2008

${ }^{21}$ Shulman, L. S. (1986). Those who understand: Knowledge growth in teaching. Educational researcher, 15(2), 4-14

${ }^{22}$ Krall, R. M., Christopher, J. E., \& Atwood, R. K. (2009). Comparison of Central Appalachian in-service elementary and middle school teachers' understanding of selected light and force and motion concepts. Science Educator, 18(1), 1-15.

${ }^{23}$ Hodapp, T., Hehn, J., \& Hein, W. (2009). Preparing high-school physics teachers. Physics Today, 62(2), pp. 40-45.

${ }^{24}$ National Academy of Sciences (1996). The role of scientists in professional development of science teachers. Retrieved from http://www.nap.edu/catalog/2310.html.

${ }^{25}$ Garet, M. S., Porter, A. C., Desimone, L., Birman, B. F., \& Yoon, K. S. (2001). What makes professional development effective? Results from a national sample of teachers. American Educational Research Journal, 38(4), 915.

${ }^{26}$ Wei, R.C., Darling-Hammond, L., \& Adamson, F. (2010, July). Professional development in the United States: Trends and challenges. Dallas, TX: NSDC. Available at www.learningforward.org/news/NSDCstudytechnicalreport 2010.pdf.

${ }^{27}$ Zepeda, S. J. (1999). Staff Development: Practices That Promote Leadership in Learning Communities. Larchmont, NY: Eye on Education

${ }^{28}$ Darling-Hammond, L., \& McLaughlin, M. W. (1995). Policies that support professional development in an era of reform. Phi Delta Kappan, 76(8), 597-604.

${ }^{29}$ Guskey, T. R. (1986). Staff development and the process of teacher change. Educational Researcher, 15(5), 5-12.

${ }^{29}$ Guskey, T. R. (2003). Analyzing lists of the characteristics of effective professional development to promote visionary leadership. NASSP Bulletin, 87(637), 4 -20. doi:10.1177/01926365030876

${ }^{30}$ Sandholtz, J., Ringstaff, C., \& Dwyer, D. (1997). Teaching with technology: creating student-centered classrooms. New York:

Teachers College Press.

${ }^{31}$ Schon, D.A. (1996). Educating the reflective practitioner: Toward a new design for teaching and learning in the professions. San Francisco: Jossey-Bass, Inc.

${ }^{32}$ Patton, M. Q. (2002). Qualitative research and evaluation methods (3rd ed.). Thousand Oaks, CA. Sage Publications.

${ }^{33}$ Yin, R.K. (2003). Case study research: Design and methods (3rd ed.). Thousand Oaks, CA: Sage Publications.

${ }^{34}$ Glasser B., and Strauss, A. The Discovery of Grounded Theory. Chicago: Aldine, 1967.

${ }^{35}$ Strauss A., Corbin J. (1990). Basics of qualitative research: Grounded theory procedures and techniques. Newbury Park, CA: Sage 